\title{
Raphael, the Virgin Mary, and Holy Matrimony: Recontextualizing Franz Liszt's Sposalizio ${ }^{1}$
}

\author{
Michele CALELla \\ Institut für Musikwissenschaft \\ Universität Wien \\ Spitalgasse 2, Hof 9 (Campus), A-1090 Wien, Austria \\ E-mail: michele.calella@univie.ac.at
}

(Received: November 2017; accepted: January 2018)

\begin{abstract}
Sposalizio, the piece opening the "Italian year" of Franz Liszt's Années de pèlerinage (first published in 1858), is one of the most analyzed and interpreted compositions in this piano cycle. Much attention has been paid to its connection with the painting of the same title by Raphael, which was printed as an internal title page for the piece's first edition at the explicit request of the composer. This connection has inspired many studies on the relationship between image and music, reinforcing the notion of Sposalizio as a musical realization of Raphael's painting as seen by Liszt for the first time in February 1838 at the Pinacoteca di Brera in Milan. Adopting a critical view of the hermeneutical tradition, which has an impact on the interpretation of the piece still today, and assuming that its composition began in Weimar only around 1848 , the article proposes an alternative reading of the piece. By connecting pictorial and musical elements, Sposalizio seems to evoke several cultural discourses and practices fundamental to Liszt's artistic and biographical background, such as Raphael's image as a genius, the revival of Marian devotion, and marriage as a sacrament of the Catholic Church.
\end{abstract}

Keywords: Liszt, Années de pèlerinage, Weimar, Raphael, Italian art

Sposalizio, the piece opening the "Italian year" of Franz Liszt's Années de pèlerinage ( $\mathrm{S}$ 161) published by Schott in 1858, is one of the most researched compositions in this piano cycle. One reason for the work's popularity lies in its alleged

1. I am grateful to Cynthia Peck-Kubaczek, Carolin Krahn, Gretl Satorius, and Scott Edwards for translating and editing the text. Thanks also to the University of Vienna and the Klassik Stiftung Weimar for funding my researches and to Evelyn Liepsch of the Goethe- und Schiller-Archiv for the assistance provided during my stay in Weimar. 
pentatonicism. ${ }^{2}$ But much attention has also been paid to the connection between Sposalizio and Raphael's painting of the same name which was printed as internal title page of the first edition at the explicit request ${ }^{3}$ of the composer (Plate 1).

Plate 1 Title page of Franz Liszt's Sposalizio (Mainz: Schott, 1858)

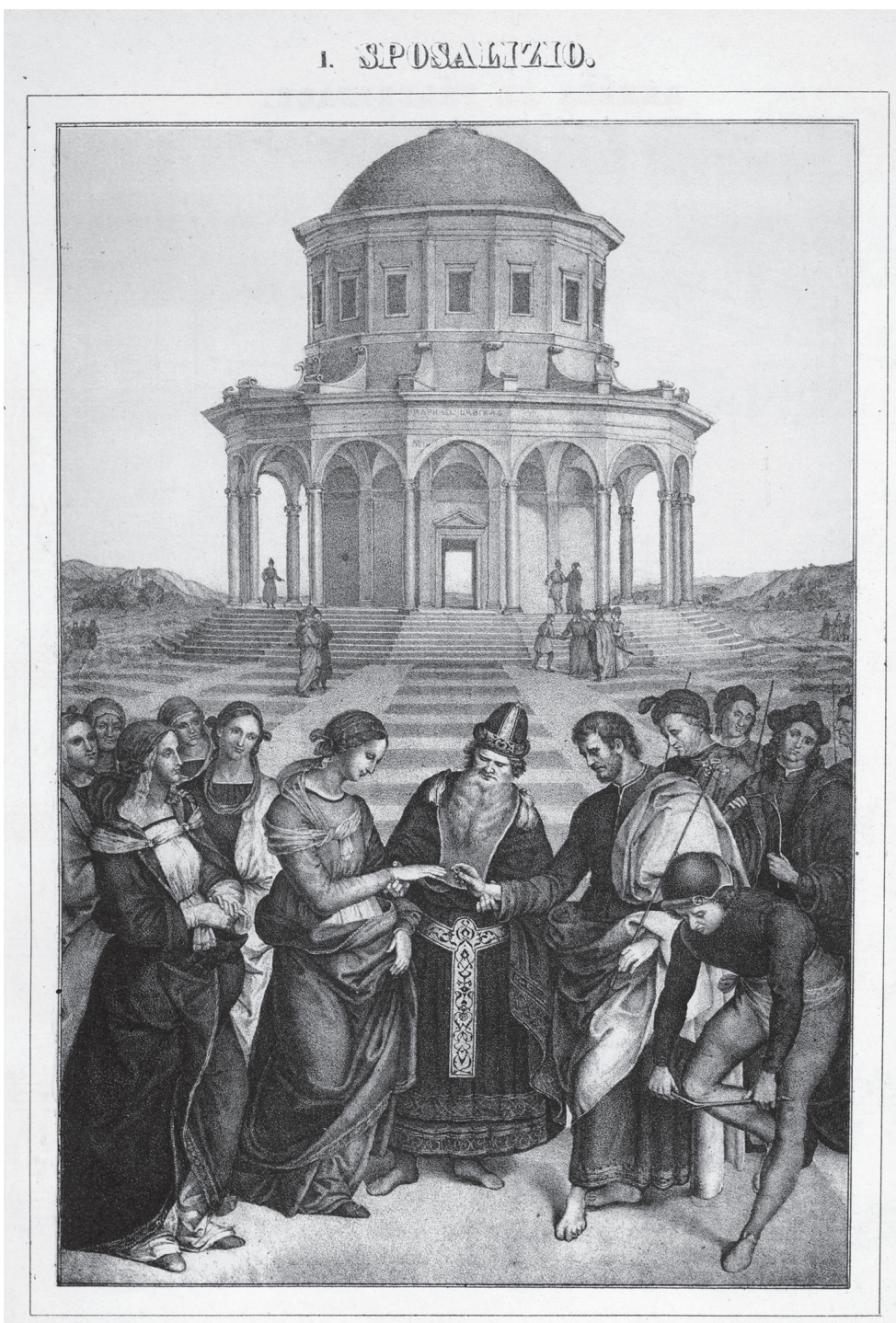

2. Cf. Jeremy Day-O'Connell, Pentatonicism from the Eighteenth Century to Debussy (Rochester, NY: University of Rochester Press, 2007), 141.

3. Letter from Liszt to the publisher Schott dated 8 December 1857, quoted in Edgar Istel, "Elf ungedruckte Briefe Liszts an Schott," Die Musik 5/3, vol. 19 (1905-1906), 49-50. 
Sposalizio and the second piece of the collection, Il penseroso, named after Michelangelo's statue of Lorenzo di Piero de' Medici in the Medici Chapel of the Basilica di San Lorenzo in Florence, are considered the first compositions to have been directly influenced by works of fine art. ${ }^{4}$ This connection is quite unusual for the time and has inspired a number of musicological studies examining the relationship between image and music. Années de pèlerinage are generally thought to mirror Liszt's cultural experiences during his travels through Italy in the company of Marie d'Agoult. As a consequence, the relationships he construed there among the various arts are mostly considered a representation of the composer's attempt to use painters and poets as role models in his search for a proper artistic identity. ${ }^{5}$ In the case of Sposalizio, the composition has been perceived as a "kindred" musical realization of Raphael's painting as seen by Liszt for the first time in February 1838 at Milan's Pinacoteca di Brera, where it is still on display. For this reason, too, it has been assumed in scholarly literature as well as in recent catalogs of Liszt's works that the piece was written in $1838-1839 .{ }^{6}$

Throughout the twentieth century and into the twenty-first, the musicological reception of Sposalizio has been quite consistent, with most studies focusing on the piece's program and its biographical context. The piece has been interpreted as a musical realization of the pictorial model, resulting in a hermeneutical tradition that has found its most detailed synthesis and formulation in the recent comparative study by Laurence Le Diagon-Jacquin:

\begin{abstract}
As has emerged from our comparative analysis, Liszt has endeavored to recreate the calm and solemn atmosphere of the painting, which depicts the biblical subject of the Marriage of the Virgin. To this end, he uses pentatonicism to produce the effect of bells, as well as a 'question-and-answer' motif to symbolize the groom's proposal and the bride's acceptance. Liszt's material can thus be associated with the pictorial model of Raphael: two motifs and a theme for the three main characters - the bride, the groom and the priest. The meaning, however, of the musical material does not correspond explicitly to the protagonists of the painting. In fact, while the single theme corresponds well to the Blessed Virgin, the motifs do not refer to Saint Joseph and the priest. It seems
\end{abstract}

4. "With this piano composition, based on the painting by Raphael of the same name, Liszt was the first in a succession of many composers who considered the visual arts a means to the ars inveniendi." "“Mit diesem Klavierstück, dem Raffaels gleichnamiges Gemälde programmiert ist, steht Liszt am Anfang einer Reihe von zahlreichen Komponisten, die bildende Kunst als Mittel zur ars inveniendi ansehen.") Monika Fink, Musik nach Bildern: Programmbezogenes Komponieren im 19. und 20. Jahrhundert (Innsbruck: Edition Helbling, 1988), (Innsbrucker Beiträge zur Musikwissenschaft 13) 16.

5. Anna Harwell-Celenza, "Liszt, Italy and the Republic of the Imagination," in Franz Liszt and His World, eds Christopher H. Gibbs and Dana Gooley (Princeton: Princeton University Press, 2006) (= The Bard Music Festival 17), 3-38.

6. See, for instance, the most recent catalog by Michael Short and Leslie Howard, Ferenc Liszt. List of Works. Comprehensively expanded from the Catalogue of Humphrey Searle as revised by Sharon Winklhofer (Milan: Rugginenti, 2004) (= Quaderni dell'Istituto Liszt 3), 28. 
that the first might be the image of bells, while the second implies the staging of the question and response between the bridal pair. ${ }^{7}$

Terms and images used in this interpretation can be traced back to musicological writings of the twentieth century, which paid special attention to the musical material of the piece and its distribution within the form. Most analyses distinguish two contrasting motifs in the opening eight-measure period. The first motif (see Example 1, mm. 1-2) consists in a melodic line of five pitch classes in the left hand spanning the range of a ninth. The sequential concatenation of an ascending major second and a falling fifth does not allow an exact tonal orientation; it ends on a B, which in the seventh chord in measures 3 and 4 suggests the dominant of E. This is followed by the second motif (Example 1, mm. 3-4), based on a falling major second and an ascending third.

EXAMPLE 1 Liszt, Sposalizio, mm. 1-4

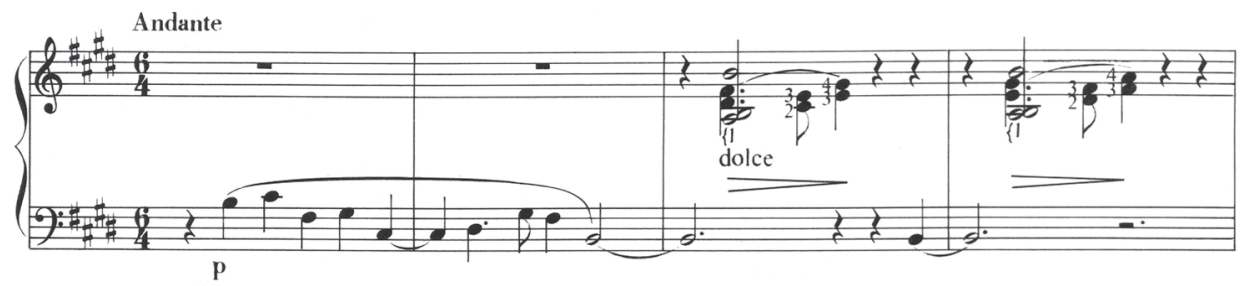

What Le Diagon-Jacquin refers to as a "theme," following the terminology of most researchers, is the melodic idea of the middle section in $\mathrm{G}$ major (Example 2). With its characteristic changing note and chordal accompaniment, the basic motif of the cantabile's theme - in ppp and una corda - can be derived from the second motif, as has been shown by Leon Plantinga. ${ }^{9}$

The whole piece, as it was printed in 1858, shows a tendency to combine and superimpose this musical material. Fragments of the pentatonic motif embellish

7. "Il se dégage de notre analyse comparée que Liszt s'attache à recréer l'atmosphère recueillie et solennelle du tableau illustrant le sujet biblique du Mariage de la Vierge. À ce dessein, il utilise le pentatonisme pour illustrer un effet de cloches, ainsi qu'un motif 'question-réponse' pour symboliser la demande et l'acceptation des deux époux. Le matériau de Liszt peut donc être associé au modèle pictural de Raphaël: deux motifs et un thème pour trois personnages principaux, les mariés et le prêtre. Cependant, la signification du matériau musical ne correspond pas explicitement aux protagonistes du tableau. En effet, si le thème unique correspond bien à la Sainte Vierge, les motifs, eux, ne renvoient pas à Saint Joseph et au prêtre. Il semble que le premier soit l'image des cloches, tandis que le second implique la mise en scène de la question et de la réponse chez les mariés." Laurence Le Diagon-Jacquin, La musique de Liszt et les arts visuels. Essai d'analyse comparée d'après Panofsky, illustrée d'exemples, "Sposalizio", "Totentanz", "Von der Wiege bis zum Grabe" (Paris: Hermann, 2009), 380.

8. Examples 1-3 and 6 reproduced after Franz Liszt, New Edition of the Complete Works, Series I, Vol. 7, Example 4 reproduced after idem, Vol. 11.

9. Leon Plantinga, A History of Musical Style in Nineteenth-century Europe (New York: Norton, 1984), 188. 
ExAmple 2 Liszt, Sposalizio, mm. 38-43

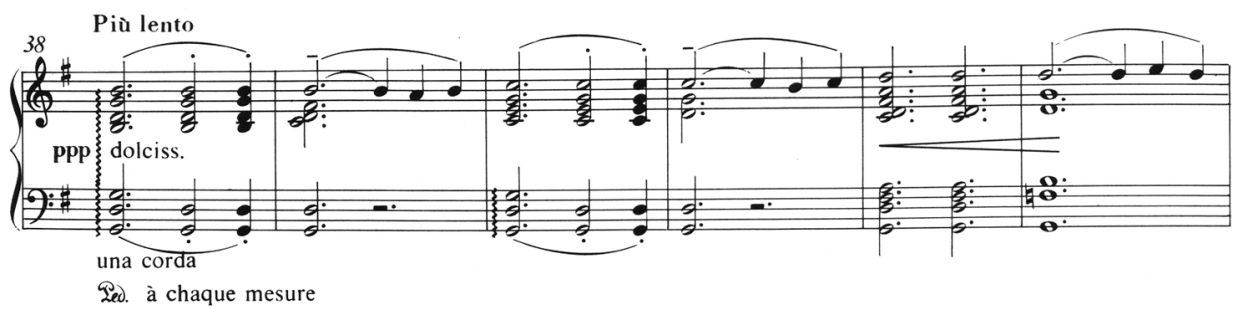

the middle section and are taken up as an accompaniment to the $\mathrm{G}$ major theme in the recapitulation of the third section (Example 3), the second motif seems to have the function of marking climatic moments in ff or fff, and the coda finally unfolds as a synthesis of the piece's various motifs.

The work of Walter Rüsch ${ }^{10}$ has been instrumental in spreading the idea that the pentatonic first motif of the composition symbolizes bells, while the G major

Example 3 Liszt, Sposalizio, mm. 74-81
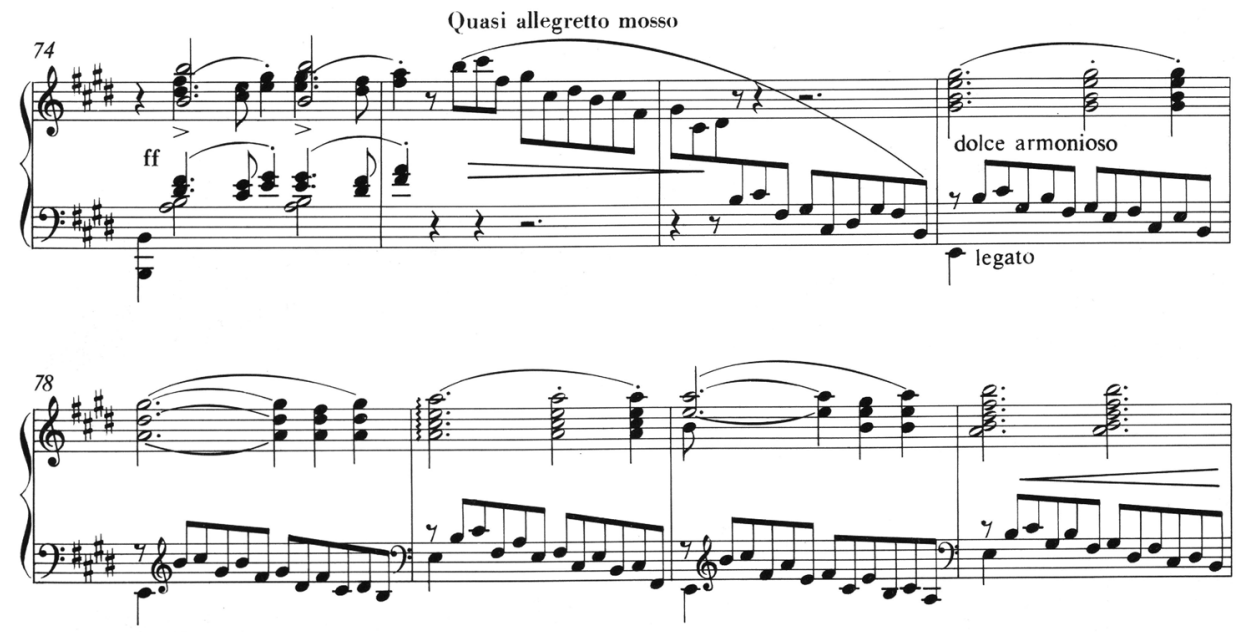

10. Walter Rüsch, Franz Liszt's Années de pèlerinage: Beträge zur Geschichte seiner Persönlichkeit und seines Stils (Bellinzona: Leins \& Vescovi, 1934), 32. Walter Rüsch, "Franz Liszt in Bellagio," in Kongressbericht Eisenstadt 1975, ed. Wolfgang Suppan (Graz: Akademische Druck- und Verlagsanstalt, 1977), $155-161$. In the later article, Rüsch states that the church bells of northern Italy - where, according to his assumption, Liszt composed the piece in 1838 - are tuned in pentatonic scales. Despite the lack of any evidence, this interpretation was taken up by Serge Gut and Jean-Jacques Eigeldinger and repeated in Liszt research of the late twentieth century. See Jean-Jacques Eigeldinger, "Les Années de Pèlerinage de Liszt. Notes sur la genèse et l'esthétique," in Revue Musicale de Suisse Romande 33/4 (September 1980), 147-172; Serge Gut, "Le profane et le religieux dans les différentes versions de l'Ave Maria de Franz Liszt," in Revue de Musicologie 76/1 (1990), 95-102. 
theme is to be understood as a hymnic Ave Maria. ${ }^{11}$ There is a certain consensus that the piece, with its contrast of motifs, tends toward a "dialogue" evolving out of questions and answers that allude, through their simultaneity in the third part, to marital union. According to Serge Gut, Sposalizio describes the divine and human couple Mary (Marie d'Agoult) and Joseph (Franz Liszt) and their union through its musical material and its treatment of it:

The musical treatment of the themes seems to confirm this hypothesis because, as has been shown, the composer interweaves the two themes in the last section of Sposalizio - as a symbol of the union of both the heavenly and the human couple, of Mary and Joseph and of Marie and Franz. The music seems to belong to the heavenly as well as the earthly sphere. ${ }^{12}$

Although some researchers have expressed a certain reserve against such a detailed and ultimately speculative musical hermeneutics, ${ }^{13}$ while others have referred primarily to formal elements of pictorial composition, ${ }^{14}$ all of them have presupposed in their interpretations an "artistic convergence" of the media of picture and music, always accompanied by the idea that Liszt sought compositionally to realize the visual aspects of the painting and their qualities. As a result, the topics of the interpretative tradition (such as the bells, the dialogue and the Ave Maria) persist even today, as the above quotation from Le Diagon-Jacquin shows.

I would like to propose a critical interpretation of Sposalizio based not so much on the visual, aesthetic experience of the composer - an experience that has

11. This persistent association with the Ave Maria is probably based on the fact that Liszt, apparently after hearing Sposalizio played by Camille Saint-Saëns on the organ, transcribed the piece for this instrument (or harmonium) with alto solo and women's choir ad libitum. This transcription was published four years after the composer's death with the title Zur Trauung: Geistliche Vermählungsmusik zum kirchlichen oder Concertgebrauch (S 60). In it, the G major theme of Sposalizio has been set to the text of Ave Maria or alternatively, for secular use, "Geist der Liebe, segne uns" (Spirit of love, bless us); see August Göllerich, Franz Liszt (Berlin: Marquardt \& Co., 1908), 166.

12. "Die musikalische Behandlung der Themen scheint diese These zu bestätigen, denn der Komponist verwebt, wie gesagt, im letzten Abschnitt Sposalizios beide Themen ineinander - als Symbol der Vereinigung des himmlischen wie des menschlichen Paares, von Maria und Joseph wie von Marie und Franz. Die Musik scheint der himmlischen wie der irdischen Sphäre gleichermaßen anzugehören." Serge Gut, Franz Liszt (Sinzig: Studiopunkt, 2009) (= Musik und Musikanschauung im 19. Jahrhundert: Studien und Quellen 14), 438.

13. See Walter Salmen, "Franz Liszt und die bildende Kunst. Zu einigen programmatischen Kompositionen," in Vermittlungen: Kulturbewusstsein zwischen Tradition und Gegenwart, ed. Hanno Helbling and Martin Meyer, (Zurich: Verlag Neue Zürcher Zeitung, 1986), 70-76; Helga de la Motte-Haber, Musik und bildende Kunst, von der Tonmalerei zur Klangskulptur (Laaber: Laaber, 1990), 92-94; Peter Andraschke, "Bild und Komposition," in Welttheater: Die Künste im 19. Jahrhundert, ed. Peter Andraschke and Edelgard Spaude (Freiburg im Breisgau: Rombach, 1992), 228-247.

14. See particularly Joan Backus, "Liszt's Sposalizio: A Study in Musical Perspective," in 19th-Century Music 12/2 (Fall 1988), 173-183, and Elizabeth Way, "Raphael as a Musical Model: Liszt's 'Sposalizio', in Journal of the American Liszt Society 40 (1996), 103-112, who interprets the piano piece according to the disposition of the figures in the space. 
been emphatically staged above all by Arnold Schering ${ }^{15}$ - but rather on Liszt's identification with several painting-inscribed cultural discourses that were central to his understanding as an artist and person living in Weimar. An important biographical prerequisite of my interpretation is the knowledge, gained from an examination of the surviving sources, that the piece was written shortly after 1848 and revised over the course of the 1850 s until its appearance in print, ${ }^{16}$ and thus at a time long after his experience in the Pinacoteca di Brera and relationship with Marie d'Agoult and in which Liszt, now in a relationship with Princess Carolyne zu Sayn-Wittgenstein, was trying to forge new compositional paths.

Regardless of the work's date of origin, it is noteworthy that Liszt seemed not to have been especially enthusiastic about Raphael's Sposalizio during his visit to Milan, although research has always stressed the aesthetic empathy for the painting expressed by Liszt in his composition. Marie d'Agoult noted the following in her diary:

\begin{abstract}
There are not very many good paintings in the Brera museum. The Wedding of the Virgin is interesting because it was painted in Raphael's early years, when he was only 21 years old, but the composition is monotonous, the painting dry, and the faces of the men are much too effeminate. Franz has no taste whatsoever for all these virgins repeated to satiety by the Italian schools. He finds their faces ordinary and completely lacking in intelligence. ${ }^{17}$
\end{abstract}

15. "In 1839 Liszt stands before Raphael's Sposalizio in the Brera in Milan. The artistic impression made by the painting is overwhelming, shattering, moving. The subject matter, form, colors, composition, sym-metry, possibly linked to art-historical or other associations, produce a tension that is released by writing a composition.” (,Liszt steht 1839 vor dem Raffaelschen Sposalizio in der Brera zu Mailand. Der künstlerische Eindruck des Gemäldes ist überwältigend, erschütternd, aufwühlend. Stoff, Form, Farben, Komposition, Symmetrien, verbunden vielleicht mit kunsthistorischen oder anderen Assoziationen, erzeugen eine Spannung, von der er sich durch die Niederschrift einer Komposition befreit.”) Arnold Schering, „Über Liszts Persönlichkeit und Kunst," in Jahrbuch der Musikbibliothek Peters 33 (1927), 31-44.

16. See the different versions in Adrienne Kaczmarczyk, "Preface," in Franz Liszt, Années de pèlerinage. Deuxième Année, Italie (Earlier Versions) and Other Works (Budapest: Editio Musica Budapest, 2010) (=New Edition of the Complete Works, Supplements to Works for Piano Solo, Vol. 13), XXXIV-LIII. Adrienne Kaczmarczyk unfortunately published here only two of the three early versions of autograph D-WRgs 60 I 16 preserved at the Klassik Stiftung Weimar, Goethe- und Schiller-Archiv, Weimar (Liszt, Années de pèlerinage, 69-71), and their presentation is often misleading. For a reconstruction of the different layers of the compositional process, see Michele Calella, "Was das Autograph erzählt: Bemerkungen zur Entstehungsgeschichte von Liszts Sposalizio," in Liszt-Jahrbuch 3 (2019/20) [in preparation]. The assumption that Liszt began the composition in Weimar is based on his use, in the autograph of Sposalizio (D-WRgs 60 I 15), of a paper Rena Charnin Mueller dates to 1848-1849; see Rena Charnin Mueller, Liszt's “Tasso" Sketchbook: Studies in Sources and Revisions (PhD diss., New York University, 1986), 376. Morerover, in the list of Liszt's compositions at the end of the Programme géneral des morceaux exécutés par F. Liszt à ses concerts de 1838 à 1848 , D-WRgs $60 \mathrm{Z}$ 15, there is no mention of Sposalizio or Il Penseroso.

17. "Le musée de Brera n'est pas très riche en bons tableaux. Les Épousailles de la Vierge ont de l'intérêt parce qu'elles sont des premiers tem[p]s de Raphaël qui n'avait guère que 21 ans lorsqu'il fit ce tableau, mais la composition est monotone [,] la peinture sèche, et les visages d'hommes beaucoup trop efféminés. Franz n'a aucun goût pour tous ces types de vierges répétés à satiété par les écoles italiennes. Il trouve ces visages communs et totalement dépourvus d'intelligence." Marie de Flavigny, comtesse d'Agoult, Correspondance générale, tome II: 1837-octobre 1839, ed. Charles F. Dupêchez (Paris: Honoré Champion, 2004), 479. This opinion is pointed out in Adrienne Kaczmarczyk, "Preface," XLVII. 
This reserved opinion of Raphael's early work, also confirmed by other ambivalent comments in Marie d'Agoult's letters ${ }^{18}{ }^{\text {is }}$ actually in contrast to Liszt's enthusiasm for the later works of the Italian painter. As Marie d'Agoult's letters show, she and Liszt then encountered paintings from Raphael's later periods in Florence and re-evaluated their opinion of him. ${ }^{19}$

Although Liszt frequently mentions Raphael in his writings and enthusiastically described Raphael's Santa Cecilia to Joseph d'Ortigue, ${ }^{20}$ it is conspicuous that the painting Sposalizio is never mentioned. Thus, the idea of Liszt having a sudden aesthetic revelation at the Pinacoteca di Brera is an assumption that finds no support in the sources.

Apart from Liszt's opinion, there are other reasons to challenge some of the traditional hermeneutic readings of the piece. Despite its popularity, the idea that the first motif of Sposalizio imitates bells - which has nothing to do with the painting's iconography but bears an implicit association with wedding bells - is problematic. The mere fact that the passage is pentatonic is not enough to support such an idea. This would require ostinato-like repetitions of a tone or a short row of tones, usually with pedaling to emphasize their resonance. This sort of effect can be found in the many passages in works by Liszt that he expressly associates with bells, such as Les cloches de Genève from the Album d'un voyageur (S 156) and the first year of the Années de pèlerinage (S 160), the early version of Harmonies du soir from the Grandes Etudes (S 137), Funérailles from the Harmonies poétiques et religieuses (S 173), Miserere du Trovatore (S 433), and Am Grabe Richard Wagners (S 202), which quotes the bells in Parsifal. In these examples, the sound of bells is realized by broken triads or simple, repeated tones in exposed, usually deep registers. Also in the Ave Maria (S 182) composed by Liszt in 1862, known by the apocryphal subtitle Die Glocken von Rom, Sposalizio's first motif, remarkably quoted here in an abbreviated form (see below), has nothing to do with the sound of the bells, which are rather evoked by deep, repeated tones in the bass in the second section of the piece.

18. "Sposalizio by Raphael is not a very beautiful painting, but it is very appealing. It was painted at the age of 20! He must have been a gift of God." ("Le Sposalizio de Raphaël n'est pas un très beau tableau mais il est excessivement attachant. Faire cela à 20 ans! Il faut être Dieudonné.”) Letter from Marie d'Agoult to Louis de Ronchaud, February 1838, Correspondance, 155. "[Sposalizio is] without a doubt an imperfect painting, but it is so pure, so simple, so chaste, our brilliant painters should come to make amends." ("[Sposalizio] Table imparfait sans doute mais si pur, si simple, si chaste, devant lequel nos peintres fantastiques devraient tous venir faire amende honorable.") Letter from Marie d'Agoult to Ferdinand d'Eckstein, 25 February 1838, ibid., 158.

19. "Raphael entirely reinstated in Florence. His second period is the sublimity of the Christian ideal, in the third he is strong, vigorous, alive like Titian with a perfection in his work that is unique." ("À Florence réparation entière à Raphaël. Sa seconde manière est le sublime de l'Idéal chrétien, Dans la troisième il est fort, vigoureux, réel comme Titien avec une perfection de travail unique.") Letter from Marie d'Agoult to Louis de Ronchaud, 3 December 1838, ibid., 240.

20. Franz Liszt, "La Sainte Cécile de Raphaël. Extrait des lettres d'un bachelier ès-musique. À M. Joseph d'Ortigue," in Revue et Gazette Musicale de Paris 6/15 (14 April 1839), 115-117. Also in Franz Liszt, Sämtliche Schriften, vol. 1: Frühe Schriften, ed. Rainer Kleinertz with Serge Gut (Wiesbaden: Breitkopf \& Härtel, 2000), 296-301. 
Furthermore, the genesis of Liszt's Sposalizio shows that the supposed dialogues between various motifs - such as the first pentatonic motif and its "answer" in the first section, representative to some scholars of a conversation between bride and groom - were not part of Sposalizio's initial conception, but were rather the result of the latest revision, in which the pentatonic motif was made more pervasive. ${ }^{21}$ One might argue that in the course of the compositional process, Liszt modified the piece's monologic character to that of a dialogue, but the question remains whether the features of monologue and dialogue in music - concepts that in any case derive from dramatic genres and not from fine art - would even need the inspiration of a pictorial model.

Beyond this, interpreting the superimposition of the $G$ major motif with the pentatonic in the third section as a reflection of the idea of a dialogue or representation of the perception of different levels in the painting (as found in articles by Joan Backus and Elizabeth Way ${ }^{22}$ must be reconsidered in light of various techniques that Liszt used in his compositional approach. Presenting and continuing themes simultaneously is a fundamental artifice in Liszt's piano paraphrases, where, in the coda, a distinctive melodic theme is often accompanied by a more dynamic theme from the same work. This technique appears quite clearly in compositions such as Réminiscences de Lucrezia Borgia (S 400), Réminiscences de Norma (S 394), and the Concertparaphrase über Mendelssohns Hochzeitsmarsch und Elfenreigen aus der Musik zu Shakespeares Sommernachtstraum (S 410), to mention only a few examples from the 1840s.

Nevertheless, one might wonder why Liszt, in his Années de pèlerinage, paid tribute to Raphael with a painting he did not particularly like. Is it possible that Raphael's Sposalizio has no relevance to the music at all? The fact that the early editions - starting even with the second edition at Schott - do not reproduce the image, and that the piece is usually played and heard at concerts without presentation of the painting clearly shows that the music works, so to speak, even without the pictorial framework. Yet, from a cultural-historical perspective, the link is not arbitrary. Just as in the case of other pieces in the first two years of the Années de pèlerinage whose music is related to landscapes, literature or fine art, this traversal of media should not be seen as evidence of the programmatic substance of the compositions, but rather primarily as the result of an aesthetically productive moment, an authorial strategy that Liszt used artistically and biographically to redefine himself as a composer after moving to Weimar in 1848. Like the Swiss album published in a definitive version in $1855,{ }^{23}$ the Italian Année de pèlerinage is not merely a diary of travel impressions or a compilation of objets trouvés. It is

21. See Calella, "Was das Autograph erzählt," [in preparation].

22. Cf. Backus, "Liszt's Sposalizio," and Way, "Raphael as a Musical Model."

23. Cf. Michele Calella, "Musik und imaginative Geographie: Franz Liszts 'Années de pèlerinage' und die kulturelle Konstruktion der Schweiz," in Die Musikforschung 65/3 (2012), 211-230. 
an elaborate, planned album that is, at many levels, symbolically connected to the cultural identity of the composer. Although the music of Sposalizio is not a faithful translation of an iconographic program, it nevertheless interacts in several ways with the cultural references found in the painting. Without losing its semantic ambiguity, the composition evokes not only the "emotions," difficult for us to decipher, that for Lina Ramann lay at the core of Sposalizio and Penseroso, but also a series of cultural motifs.

With its reference to Raphael, Liszt's Sposalizio was inscribed into an early nineteenth-century historical-aesthetic discourse, in which the Italian painter represented an "absolute" artistic ideal. The esteemed position of Raphael as the artist who reestablished an ancient model of beauty had been a basic tenet since the writings of Johann Joachim Winckelmann from the 1750s and 1760s. ${ }^{24}$ This position also affected discourse on music and aesthetics, as can be seen by the frequent comparison of Mozart to Raphael, first put forward by Johann Friedrich Rochlitz in an article in the Allgemeine musikalische Zeitung in $1805 .{ }^{25}$ It was a comparison that then became decisive for the image of the composer during the nineteenth century. ${ }^{26}$ The coupling of Raphael and Michelangelo corresponded to a common tendency in art-historical works of the early nineteenth century to place the two artists in a relationship of dichotomous tension. This was influenced by the description of the two artists in the Vite of Giorgio Vasari, where the "graceful" and "heavenly" art of Raphael is compared to the "terrible" and "mighty" works of Michelangelo. In the first half of the nineteenth century, Raphael was established as a "smooth" painter of female religious figures, especially images of the Madonna, who aroused devotion and trust in the viewer. In contrast, the troubled and strange figures of Michelangelo were thought disturbing for viewers. ${ }^{27}$ In this sense, it is clear that the musical characters of Sposalizio and Il penseroso were already determined by the names of the artists, independent of the exact choice of their works. This dichotomy also makes it obvious why Liszt did not choose a painting by the more mature, philosophical Raphael, such as those found in the Stanze di Raffaello at the Vatican, which were reappraised by critics, especially in the second half of the nineteenth century ${ }^{28}$ In any case, this cultural ascription

24. On this, cf. Christoph Schmälzle, "Klassizismus zwischen Renaissance und Griechenkult: Raffael als Ideal," in Raffael als Paradigma: Rezeption, Imagination und Kult im 19. Jahrhundert, ed. Gilbert Heß, Elena Agazzi and Elisabeth Décultot (Berlin/Boston: de Gruyter, 2012), 97-122.

25. Cf. Martin Staehelin, "Mozart und Raffael: Zum Mozart-Bild des 19. Jahrhunderts," in Schweizerische Musikzeitung 117 (1977), 322-330, and Ulrich Konrad, "Friedrich Rochlitz und die Entstehung des Mozart-Bildes um 1800," in Mozart - Aspekte des 19. Jahrhunderts, ed. Hermann Jung (Mannheim: Palatium, 1995) (= Mannheimer Hochschulschriften 1), 1-22.

26. Cf. the list of relevant articles in Constantin von Wurzbach, Das Mozart-Buch (Vienna: Wallishausser, 1869), 232.

27. Kerstin Schwedes, "Raffael und Michelangelo: Renaissance - Barock?," in Raffael als Paradigma, $239-253$.

28. Ibid., 245. In this sense, Liszt's image of Raphael corresponds to the ideas of Johann David Passavant, whose monograph the composer came across on 25 October 1839. See the letter from Franz Liszt to Marie 
would not allow the "subjects" of the two pieces to be interchanged. The gentle nature of Sposalizio's themes and coda, seen in markings such as dolce, dolcissimo and sottovoce, clearly differs from the sorrowful character of Il penseroso, with its funeral march in $\mathrm{C}$ sharp minor, interpreted by some as a reference to Beethoven. ${ }^{29}$ This is also consistent with the analogy between Beethoven and Michelangelo that characterized the early reception of Beethoven. ${ }^{30}$ The gender dichotomy of the two subjects - a painting of Mary by Raphael, a sculpture of a man in an architectural space predominantly displaying male characters by Michelangelo - corresponded to a basic viewpoint in Vasari's reception of the two artists, a reception that ultimately became very powerful in the nineteenth century. ${ }^{31}$ This is clearly expressed in Ramann's interpretation of Il penseroso:

Just as Michel Angelo's statue is not only noble but also masculine, in Liszt's harmonies there is a harsh pain, but the heart does not falter or tremble. The 'thought' prevails further and further, a basso continuo evokes a powerfully pondering movement that becomes a religious feeling. But also this, the religious feeling, is part of this discipline of thinking - there is no free upsurge, nor is any offense of this sort expressed here. It echoes in the mind, which comes again to the fore and sinks back solemnly, as it began, into the male breast. $^{32}$

The fact that Liszt chose a picture of Mary was not random. Rather, it is a direct homage to the Virgin, a central figure in the Catholic faith, whose cult was enjoying resurgence in his time.33 This active veneration of the Virgin Mary, which flourished particularly in the first half of the century, was also promoted by Pope Pius

d'Agoult (Venice, 25 October 1839), in Franz Liszt/Marie de Flavigny d'Agoult, Correspondance, ed. Serge Gut and Jacqueline Bellas (Paris: Fayard, 2001), 384.

29. David A. Damschroder, "Liszt's Composition Lessons from Beethoven (Florence, 1838-1839): Il penseroso," in Journal of the American Liszt Society 28 (1990), 3-19.

30. Cf. Alessandra Comini, The Changing Image of Beethoven: A Study in Mythmaking (Santa Fe: Sunstone Press, 22008), 92; Raphael Rosenberg, Beschreibungen und Nachzeichnungen der Skulpturen Michelangelos: Eine Geschichte der Kunstbetrachtung (Munich/Berlin: Deutscher Kunstverlag, 2000) (= Kunstwissenschaftliche Studien 82), 46.

31. Cf. Philip Sohm, "Gendered Style in Italian Art Criticism from Michelangelo to Malvasia," in Renaissance Quarterly 48/4 (Winter 1995), 773-774, and Maike Christadler, "Kreativität und Genie: Legenden der Kunstgeschichte," in Kunstgeschichte und Gender. Eine Einführung, ed. Anja Zimmermann (Berlin: Reimer, 2006), 258.

32. "Wie die Statue Michel Angelo's nicht allein edel, sondern auch männlich ist, so zuckt wohl durch Liszt's Harmonien ein herber Schmerz, aber das Herz stockt nicht und zittert nicht. Der 'Gedanke' geht herrschend weiter und weiter, ein basso continuo spricht von mächtig-sinnender Bewegung, die zu religiösem Gefühl wird; doch auch dieses, das religiöse Gefühl, steht unter der Gedankenzucht - kein freier Aufschwung, doch auch kein Vergehen desselben spricht sich hier aus. Es hallt in dem Sinnen nach, das wieder in den Vordergrund tritt und ernst, wie es begonnen, zurücksinkt in die männliche Brust." Lina Ramann, Franz Liszt. Als Künstler und Mensch, vol. 1: Die Jahre 1811-1840, (Leipzig: Breitkopf \& Härtel, 1880), 530.

33. Cf. Michela de Giorgio, "Die Gläubige," in Der Mensch des 19. Jahrhunderts, ed. Ute Frevert and Heinz-Gerhard Haupt (Frankfurt/New York: Campus, 1999), 120-147. 
IX, whose own Marian devotion was very strong, in particular with respect to the Ineffabilis Deus bull of 1854 defining the dogma of the Immaculate Conception. 34 In the course of this rekindled interest, above all encouraged by the writings of Alfonso Maria de' Liguori and Louis-Marie Grignion de Montfort, Marian devotions such as the rosary and May devotions experienced a rapid upswing. ${ }^{35}$ Franz Liszt also experienced a resurgence of his religiosity and an increased interest in church music and Marian music in Weimar, ${ }^{36}$ especially due to the influence of Carolyne zu Sayn-Wittgenstein, who was a fervent Catholic and well educated in matters of theology ${ }^{37}$ Joachim Raff once told William Mason that Liszt often had intense phases of prayer, during which he threw himself on the ground in front of a statue of Mary and stayed in this position for long periods..$^{38}$

Could Sposalizio thus be a musical act of devotion? An explicit reference to liturgical melodies cannot be found, in contrast to other compositions of this period such as Ave Maria, Pater noster, Miserere d'après Palestrina from the Harmonies poétiques et religieuses published in 1853, and Totentanz (S 126/1). Nonetheless, although it does not sound like a plainchant melody, the beginning of Sposalizio is characterized by a diatonicism that is tonally vague, making the "Old Roman" character as described by Ramann ${ }^{39}$ a more apposite evocation than any ringing of bells. Moreover, the melody presented in a single voice and the deliberate blurring of the rhythmic beat evoke the impression of an imaginary plainchant. Yet, this melody is hardly vocal, given its unusual structure of a sequence-like repetition of a whole tone and falling fifth. Although the intervals of this motif change according to the respective harmonies and lose their pentatonic character, the outline of its motivic cell is kept in the case of final gestures or the start of new sections, such as in measures 27,30 and 31. An abbreviated quotation of this motif is found as a kind of motto in the brief introduction and coda of Liszt's Ave Maria, composed in Rome in 1862 (Example 4). While it does not feature the same pentatonic range, it is in the same key as Sposalizio.

34. Veronika Maria Seifert, Pius IX. - der Immaculata-Papst: Von der Marienverehrung Giovanni Maria Mastai Ferrettis zur Definierung des Immaculata-Dogmas (Göttingen: V\&R unipress, 2013).

35. Ibid., 53.

36. Cf. the Ave Maria in the Harmonies poétiques et religieuses, the Litanies de Marie for piano, which were probably composed in 1847, and the Ave Maria for choir [S 20i], composed in the 1840s.

37. See Alan Walker, Franz Liszt: The Weimar Years 1848-1861 (Ithaca, NY: Cornell University Press, 1993), 11-12.

38. "Joachim Raff, long his intimate friend and associate, told me that these periods were sometimes of considerable duration, and while they lasted he would seek solitude, and going frequently to church, would throw himself upon the flagstones before a Muttergottesbild, and remain for hours, as Raff expressed it, so deeply absorbed as to be utterly unconscious of events occurring in his presence." William Mason, Memories of a Musical Life (New York: The Century, 1901), 144.

39. Ramann, Franz Liszt, 528. 
Example 4 Liszt, Ave Maria, mm. 1-5

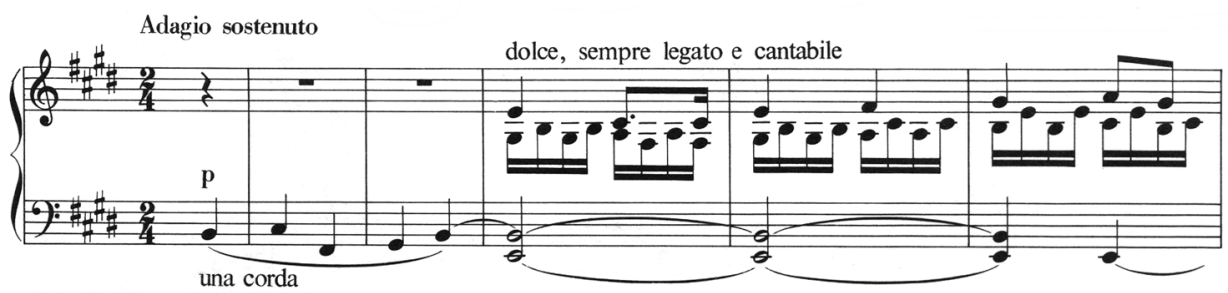

To some extent, it seems that Liszt associated this motif with Mary; in both pieces it appears in a single voice as a tonally ambiguous introduction to a melodically and tonally rounded theme. Actually, there is a liturgical melody with a distinctive descending fifth to which the beginning of Sposalizio might allude. It is not by chance a Marian melody: this is the Salve Regina in Dorian mode (see Example 5), an antiphon that not only takes a fixed liturgical place in Compline and Vespers, but which was also widely sung in popular devotional practices.

ExAmple 5 Salve Regina in D, incipit

Liber Antiphonarius pro diurnis horis juxta ritum romanum

(Solesmes: Typographeo Sancti Petri, 1897)

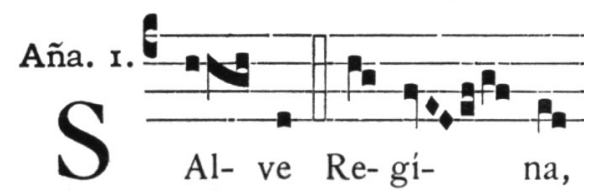

This melody was apparently the most popular Salve Regina melody in France, as testified by its presence in various textbooks on Gregorian chant. ${ }^{40}$ Liszt himself used this melody for the first of his Zwei Kirchenhymnen for organ, composed in 1877 (S 669/1).

Although the first tone of the melody in Sposalizio is replaced by a rest, the combination of ascending whole tone and falling fifth gives the melodic line of this motivic fragment its special character. Indeed, in the final version, where motif A is more pervasive, this melodic motto is clearly recognizable before the Andante quieto (see Example 6).

40. Cf., for example, Trois méthodes faciles pour apprendre le plain-chant en peu de temps (Lyon: Aynés, 1813), 27; Abbé G***, Nouvelle méthode de plain-chant parisien, ou Exposition claire et précise des principes du plain-chant (Dijon: Douillier, 1829), 108; Jean-Baptiste Mathieu, Nouvelle méthode de plain-chant, à l'usage de toutes les églises de France (Paris: Angé, 1838), 61. 
EXAMPLE 6 Liszt, Sposalizio, mm. 27-29

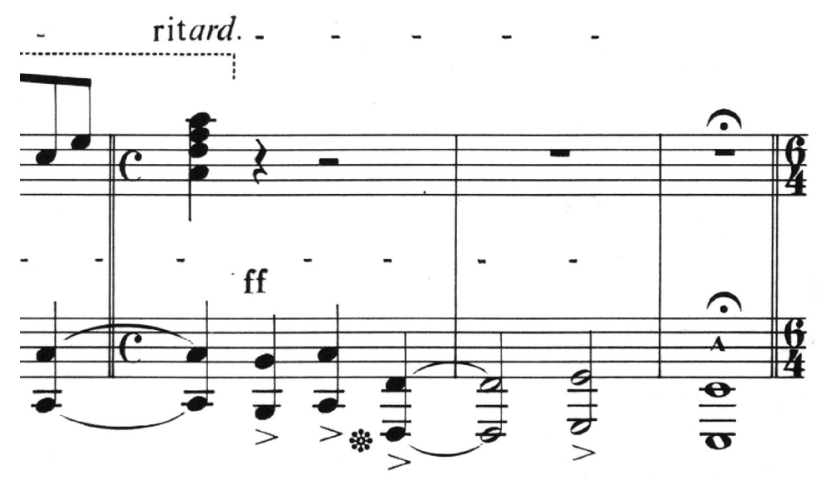

Could the $\mathrm{G}$ major theme of the middle section also be based on a Marian melody? According to Walter Rüsch, this theme is similar to the folk litanies sung in northern Italy. ${ }^{41}$ His hint, however, has been overlooked in later interpretations of the piece. Rüsch does not substantiate his claim but setting aside any purported oral traditions in northern Italy, we need only look at melodies associated with the most popular modern Marian litany, the Litany of Loreto (also known as Lauretanae), to find resemblances. Adrien de La Fage, in his Cours complet de plainchant, describes the given melody as characteristic of Marian litanies in Italy, ${ }^{42}$ too, but there is evidence that this melody was also used in other places in the nineteenth century. ${ }^{43}$ The usual melodic phrase (see Example 7) contains two melodic cells in the range of a minor or major third, each with the characteristic changing note and a rising second.

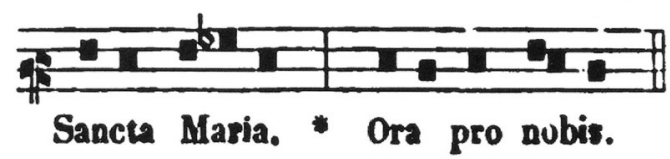

41. Rüsch, "Franz Liszt in Bellagio," 159-160.

42. Adrien de La Fage, Cours complet de plain-chant, ou nouveau traité méthodique et raisonné du chant liturgique de l'église latine. A l'usage de toutes les diocèses (Paris : Gaume Frères, 1855), 373-374.

43. For example, this melody can be found - tellingly in G major, just like in Sposalizio - in a Catholic hymnal featured in Liszt's library: Franciscus Zsasskovszky, Manuale Musico-Liturgicum ... in Usum Ecclesiarum Cathedralium et Ruralium (Agria [Eger]: Typis Lycei Archi-Episcopalis, 1853), 209. (Today in the Liszt Library of the Herzog in Anna Amalia Bibliothek in Weimar, signature: L 204.) The specific "Italian" connotation of this melody can be seen ex negativo by the fact that Liszt uses a different melody in his unpublished Litanies de Marie (D-WRgs 60 I 34). 
The similarity between these motifs and the second "answering" motif at the beginning of Sposalizio as well as the related G major theme is noteworthy. It is interesting that Backus, perhaps influenced by Rüsch, describes the $\mathrm{G}$ major theme as "processional," 44 since the litanies of the Virgin Mary were usually prayed at the end of the procession of the Rosary, ${ }^{45}$ even before Pope Leo XIII combined the Rosary and litanies for the month of October in the Supremi apostolatus officio bull of 1883. Furthermore, it needs to be underscored that the Salve Regina plays a central role in the Rosary. ${ }^{46}$ It cannot, however, be stated with certainty that Liszt intentionally referred to these specific Marian devotional practices. Nonetheless, it is clear that Sposalizio not only pays homage to the "divine" art of Raphael, but also may be interpreted as an expression of his intense Marian devotion. ${ }^{47}$

There is still one open question: why did Liszt choose Sposalizio and not another Madonna by Raphael, since he apparently considered the painting Sposalizio not particularly interesting? The answer has less to do with the painting's aesthetic qualities than with its subject matter. Marriage was a very sensitive topic in Liszt's early Weimar years. When he met Carolyne zu Sayn-Wittgenstein in 1846, she had been separated from her husband for three years. Before moving to Weimar, she requested a marriage annulment, hoping for a positive outcome and an imminent wedding. A long negotiation process ended with a disappointing rejection by the church authorities in $1861 .^{48}$

Against this background, the prominent position of Sposalizio in the cycle of the Années de pèlerinage confirmed the holiness of marriage as a sacrament according to the Catholic Church and re-embodied a wish that Liszt and Carolyne cherished the entire time they lived together in Weimar (1848-1861). The fulfillment of this hope depended on a decision by Pope Pius IX, who, as previously mentioned, was a devout venerator of the Virgin Mary.

Considering Liszt's Sposalizio as a musical symbol for the holiness of marriage is suggested by a comment made by Carolyne zu Sayn-Wittgenstein in 1879 . When she gave Lina Ramann the editions of Matrimonio/Ehe and Communion from Liszt's Septem Sacramenta for choir and organ (1879), the future Liszt biographer Ramann asked her opinion about the aesthetic quality of the pieces. In response, the princess emphasized the immaterial character of the compositions,

44. Backus, "Liszt's Sposalizio," 175.

45. Cf. Louis de Sambucy de Saint-Estève, Manuel du chapelet et du rosaire de la sainte Vierge, d'après les documents les plus authentiques (Paris : Gaume Frères, 1837), 115.

46. Ibid., 88-89.

47. It is perhaps no coincidence that the piece is in the key of E major, which Liszt often used during this period for Marian compositions. Cf. Paul Merrick, “Two Keys for Six Pieces: Tonality and Liszt's Consolations," in Journal of the American Liszt Society 54-56 (2003-2005), 125-133.

48. See the well-documented account in Alan Walker, Liszt, Carolyne, and the Vatican: The story of a thwarted marriage (Stuyvesant, NY: Pendragon Press, 1991). 
declaring herself unable to speak about anything purely spiritual. She did, however, draw a comparison to Sposalizio:

But perhaps you may be interested to hear that in Matrimonium I feel a reso-
nance of Liszt's Sposalizio - I say 'feel,' for it cannot be grasped or analyzed.
Both of them - Mat. and Spos. - ring with the same spirit to me, the same
mood, although the mood of Matrimonium is no longer earthly. The two bliss-
ful harmonies that reverberate at the end of Sposalizio are so transfigured that,
rather than equaling worldly sounds, they resemble the last breath of sunset,
where heaven and earth flow into one another and yearn to slip out of sight. ${ }^{49}$

Sposalizio and Matrimonium have little in common. Nonetheless, Carolyne zu Sayn-Wittgenstein's comparison of the two pieces implies that thirty years after Sposalizio's composition and twenty years after its publication, she "felt" that the piece primarily had to do with the sacrament of matrimony, a motif which came with a special biographical, as well as religious, significance for her. This pictorial motif also accompanied Liszt for a long time, despite his disappointment in the marriage annulment being rejected. This is testified by an image that hung in Liszt's house at the Hofgärtnerei in Weimar and is still there in his bedroom: a hand-colored print of a drawing by Moritz von Schwind, Vermählung der Heiligen Elisabeth mit Ludwig dem Heiligen von Thüringen (The wedding of Elizabeth and Ludwig, Saint of Thuringia, reproduced in Plate 2), the original now kept by the Kupferstichkabinett of the Staatliche Museen zu Berlin. ${ }^{50}$

Despite the different posture of the bride and groom, the Schwind image shows, in its overt historicism, a certain resemblance to Raphael's painting especially in regard to the symmetry of the characters, the central position of the priest and the crucifix in the church choir correlating with Raphael's temple. Here, too, marriage is associated with a saintly female figure, in this case one that was central to Liszt's Catholic, Hungarian and German identity.

With respect to Sposalizio, Lina Ramann described Raphael's painting as a "program without words." 51 But how should the word "program" be understood here? Scholars have treated the painting as a model that influenced the musical

49. 'Doch interessirt es Sie vielleicht zu hören, daß ich im 'Matrimonium' Liszt's 'Sposalizio' wiederoder: nachklingen fühle - ich sage 'fühle', denn greifen und analysiren läßt sich das nicht. Mir hallen beide Matr. und Spos. - denselben Geist, dieselbe Stimmung wider, nur bei dem 'Matrimonium' letztere abgezogen vom Irdischen. Zwei wonnige Harmonien, die aus dem 'Sposalizio' nachklingen, sind so verklärt, daß sie mehr dem letzten Hauch des Abendrothes, wo Himmel und Erde ineinander geflossen dem Auge entschwinden wollen, gleichen als irdischem Klang." Lina Ramann, Lisztiana. Erinnerungen an Franz Liszt in Tagebuchblättern, Briefen und Dokumenten aus den Jahren 1873-1886/87, ed. Arthur Seidl (Mainz: Schott, 1983), 139.

50. Catalog of the Liszt House, GNM No. 54a. The original is preserved in the Kupferstichkabinett of the Staatliche Museen zu Berlin (Ident. No. SZ Schwind 10) and dated 1857. I would like to thank Ilona HaakMacht (Klassik Stiftung Weimar) for drawing my attention to this painting.

51. Ramann, Franz Liszt, 528. 
Plate 2 Moritz von Schwind, Vermählung der Heiligen Elisabeth mit Ludwig dem Heiligen von Thüringen

(C) Kupferstichkabinett Berlin (Staatliche Museen zu Berlin Preußischer Kulturbesitz), published under CC license

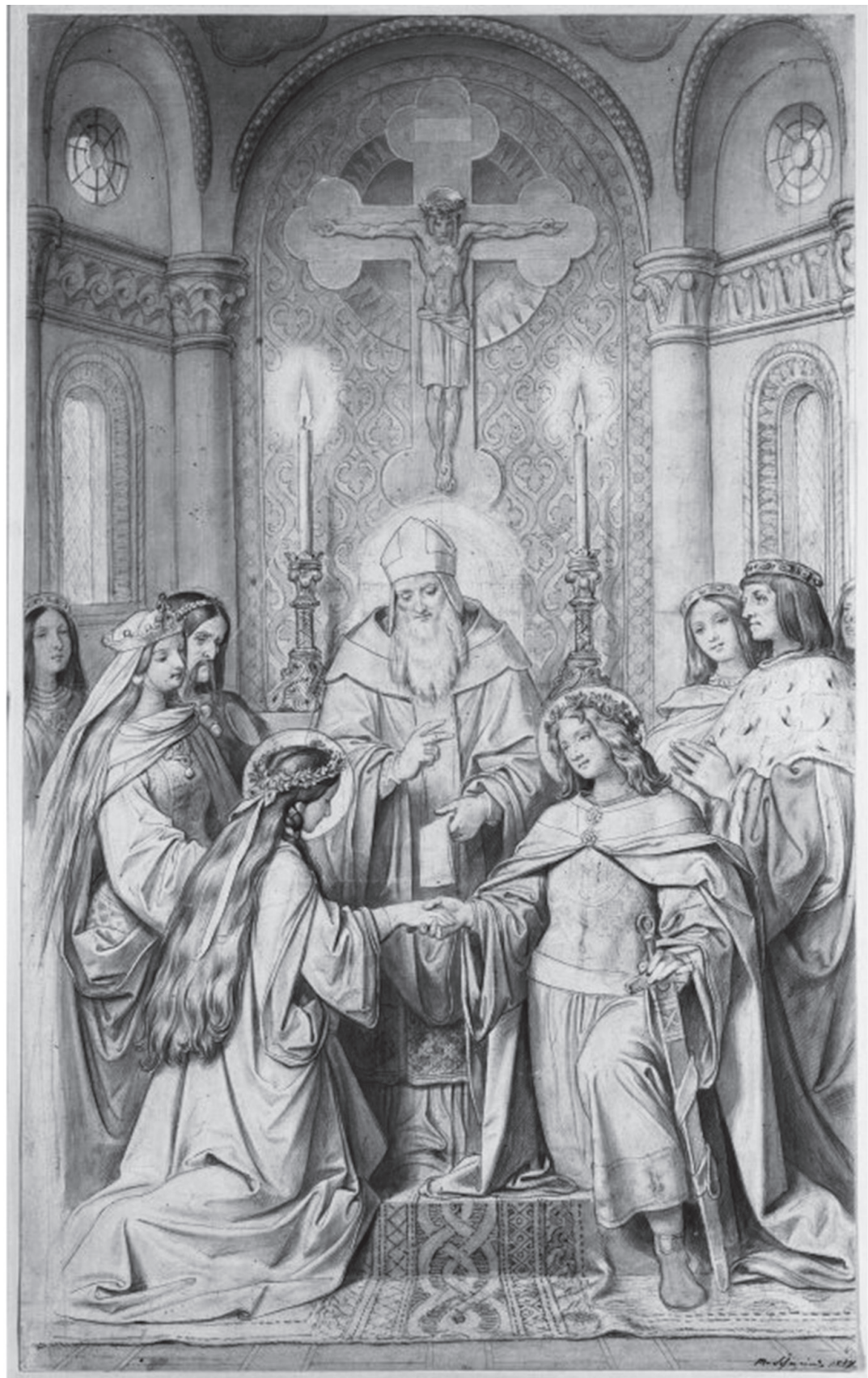


substance of Liszt's piece as well as its formal construction. This resulted in a number of assumptions about the work, especially the suppositions that it was inspired by Liszt's journey to Italy and written as an homage to Marie d'Agoult, and comes down to a musical portrayal of the motifs and formal elements of the painting. Considering Sposalizio a piece from Liszt's Weimar period, I have attempted to retain the piece's semantic ambiguity and interpret the coupling of music and image more as a discursive network than as an imitation of pictorial program. As demonstrated above, at least three key motifs of Liszt's aesthetics and personal biography around 1850 can be related to Sposalizio: the romantic cult that viewed Raphael as a religiously shaped artistic ideal, the revival of Marian devotions, and the holiness of matrimony as a sacrament of the Catholic Church. 